\title{
A Glance on Environmental Protection in Africa: Theological Perspective
}

\author{
*Kalemba Mwambazambi
}

\begin{abstract}
The wish is that environmental protection be a permanent individual and collective responsibility for African intellectuals and all human community. Using conceptual tools, environmental, management and theological critical analysis, it can allow showing how well concepts such as politics, economy, war, culture, technology, urbanization, globalization, and theology are linked to ecology, which means the relationships between them and the surrounding nature. Consequently, African intellectuals and different theologians need also to take into account and help observe ecological norms in the fulfillment of their world mission. Affirm Mugambi (2001) "human beings and nature as such are valuable and deserve to survive". Therefore, global and local actors must take appropriate responsibility in order to ensure the ecological balance that will sustain life on this planet.
\end{abstract}

Key terms: Africa; Creation; Human beings; Protection; Ecology; Environment; Theologians.

\section{Introduction}

$A_{\text {contributes little to climate }}^{\text {s a developing continent, Africa }}$ change yet it will be the continent among the first ones to be hit quite hard by the impacts of various climatic turnovers. More than 180 million persons could be affected by the consequences of climate change in subSaharan Africa by the end of the century. This is the reason why it is fundamental to attack the environmental problems in Africa for the future generations and the whole world. So, Africa should turn decisively to the renewable energies and take the head of the African shutter of the energy revolution to reduce climate change. And the Democratic Republic of Congo can fight for the protection of the tropical bits threatened by the industry of the wood in the pond of Congo because it risks losing $40 \%$ of its bits in the next forty years. That is why, Africa need to fight climate change, deforestation, water pollution, etc., and respond positively on the urgent problems connected with the environmental protection. In fact, the impact of the industrial pollution of the industrialized nations constitutes an important threat and climate change challenges to the populations and more particularly in Africa because, pollution, deforestation, erosion of soil, drought and floods have increased with the desperate state of the continent, as stated by Mugambi (2001) "it is clear that poverty, the model of the international business and imbalance in the political power between the rich and poor countries contribute to the ecological problems in Africa". Obviously, the international factors contribute to the environmental disaster in Africa because of causal connection between total pollution and international capitalism in the form of economic consumerism and the liberalism that play a great role in the environmental destruction, and it seems difficult to ignore the environmental crisis which disturbs human life in Africa. Accordingly Mugambi (2001) observes "the life of large populations is compromised by the degradation of the environment caused by micro-economic and total practices of corporation". That is why it is necessary that African intellectuals and leaders conscientise their people to fight all forms of destruction of nature in order to protect the environment according to the vision of God. Writing further in this connection, Mugambi (2001) advises, "the churches particularly can conscientise their people by the pastoral consultation to protect nature". It is thus important that the intellectuals help the African peoples to protect their environment according to the ordinances of God.

\section{Background and development}

In this article, a qualitative research method was used. In fact, the third millennium world, in particular, its economy calls for ecological awareness as interface indispensable for needed vitality and sustainability. In other words, if Africa needs a vital and sustainable economy, it needs to be very careful and serious about ecological fallouts because ecology and economy go hand in hand as inseparable couples. Unfortunately, the destruction of fauna and flora in French and English Africa by aggression armies, the looting of natural resources, are done without calculating the ecological consequences of economic choices. Unawares, Africans sometimes find themselves under the threat of the food they are eating, air they are breathing, that constitute unimaginable self-destruction 
sanitary risk, leading to worst cataclysms and catastrophes of history because of pollution and non-respect of the norms of natural resources exploitation. That is why I deem that rational and honest planning as to how the exploitation of the natural resources in Africa should be done is of paramount necessity. Accordingly, Coste (2000) says, "the will of God was that human being commune with nature as his/her intelligent and noble master and guardian, and not as his/her exploiter and destructor denude of any management". Unfortunately, Africans are still consumers of polluted goods and behave like toys in the hands of great economic powers of the world. Consequently, African nature will continue to fall victim of the very powers as well. Therefore, if industries and great powers, in the name of profit, pollute everything, there is no equitable and balanced management of the environment after God's will. Management after his will require taking into account values, especially, ecological values such as environment protection, the protection of soil and sub-soil, of forests, of waters, brief, of flora and fauna. Fighting pollution, deforestation, erosions, bush fires and the misuse of the African soil is necessary for the protection of the African people, for God meant them to lead a healthy life in the healthy environment. It is a common notice that in most cases, these ecological norms are often sabotaged by the very people who elaborated them, because deep in them lies a huge and dangerous "love of money" (1 Tim 6:10). The Democratic Republic of Congo is a case in point. The country is potentially so rich; its soil and sub-soil, flora and fauna are naturally very rich. Those who know too well about these riches are the economic, military and political great powers of the world. This scandalous wealth of the country is exploited with such greed and violence that it makes its people miserable; they are being imposed ruthless and cruel leaders, those who serve well foreign powers and impoverish their own people and kill them. In the name of the foreign profit, the environment is destroyed and polluted, people exploited and killed. Should as Christians, Christian workers, missiologists, theologians, or intellectuals sit back and look with indifference? No! That is a crime. I think that, Africans should stand and fight by all means. Aware of such global abuses, Biber (2004) also denounces "over-consumption and overexploitation that deplete or dangerously diminishes natural resources that God has given to human beings for proper management". In this connection, Coste (2000) also remarks, "instead of fulfilling their role as collaborators of God in the work of creation, the economically strong people choose to take the place of God, ending up provoking the revolt of nature that is more tyrannized than governed by them". Of course, economy is actually linked to ecology, but still remains within the frontiers of political power. I estimate if the African people want Africa to develop and prosper in peace, they must oppose anything that kills the continent. African elite, may it be, ecologists, politicians, theologians, economists, educators/researchers, sociologists, and all others are called now to spearhead this struggle in integrity to protect their environment. The bet for peace is about to be won; the war is to be fought and every element of the creation has to pay the price. Africans should stand up and fight to the end for the protection of the environment.

\section{Overview of environmental degradation causality in Africa}

Africa has been suffering serious degradation through recent decades. Various causes are at the origin of this environmental destruction, namely, several wars due to selfish interests supported directly or indirectly by Westerners, bad strategies of industrialization adopted by many African countries, deforestation, desertification, pollution of water, air, land, climate change, bad governance and unplanned development strategies and mismanagement of natural resources etc. South Africa is an African country that has contributed to air and water pollution more than other African countries through recycling industry, oil and electricity production from goal, and various transformation industries. In fact, the exploitation of the African nations by their former colonial rulers continued after decolonization. Not only all the social structures of Africa have suffered total and systematic dilapidation by the hands of these powers, but also the total destruction of the ecological system. The political and military crisis in the Great Lakes Region (Burundi, Democratic Republic of Congo and Rwanda) has terribly affected the environment in this part of Africa. The immigration of Rwandan 
refugees into Congolese territory in 1994 seriously worsened the environment of Democratic Republic of Congo. Forests and animals of the area where the refugees were living were the first victims. They devastatingly cut trees to cook their food or warm themselves up and indiscriminately kill animals either for food or to start a small business. They would sometimes destroy environment for fun. The terrible situation of repeated wars that started in 1996 and seems to continue has been a horrible one for both people and environment. A lot of men and women and their children died. Affirm Biber (2004) "the estimates speak of more than three million of them dead. To this Africans have to add at least one hundred thousand Rwandans refugees who were found dead during the socalled liberation of the 1996". This situation entailed huge massacre, extensive lootings, horrible raping of women and little girls, weeping, resentment, vengeance spirit, total rune and impoverishment; in brief, complete unprecedented human, material and environmental desolation, ecological and humanitarian devastation was thus complete. This situation challenges each one of African and that of the minority of those who claim to be defenders of the creation theologically speaking. Therefore, it is high time Africans had stood up to fight against the destruction of African environment, and the environmental degradation leads to generalized pollution. Quantity of household wastes thrown into water points and rivers and the multiplication of nuisances and water-born diseases prove how polluted is water in the country. Unfortunately, this situation does not worry either political authorities or those in charge of water distribution. The soil is under the serious threat of erosions in Kinshasa, the capital city of the country, at Mbuji-Mayi and Bandundu, but the causes are numerous. Let me enumerate a few: anarchic constructions that observe almost no urbanization norms, stopped swages all-over the city that could no longer control torrential rain water, but also savage deforestation in the rural milieus. Mataba erosion (Ngaliema) is one of the most dramatic examples at Kinshasa and Kalala wa Nkata at Mbuji-Mayi. I think that, humans in general and Africans in particular, need salutary air to live a healthy life. Unfortunately, African people are often deprived of such hygienic air because, it's generally polluted by dust from streets, smokes from bush fires, household works, vehicles, cigarette smoking, smelly odors, dirty wastes, and sometimes from some weapons used in wars fought through the continent. These pollutions have unprecedented consequences. That is why Africans theologians have to raise awareness among other Africans intellectuals from different fields and institutions and even among other people of the world who can help. Such awareness and struggle for the protection of the environment and climate change is important because environment can play an important role for or against Christian mission in the continent. Affirm, Tron (1999)

Nature has a role to play around us and secretly fulfill it as yet as humans leave her a little bit of the space. Polluted damaged places are no good but for rats and pests; but if we give her a chance to settle in a favorable space, we will see flowers, singing birds and butterflies reappear for our rejoicing and amazing of all; first of all, that of our children. I therefore claim environment and blooming of all, trees for our lungs, flowers for our smiling and birds for our dreams.

The statements above convince me that humans can well take profit of the environment that they respect and with which they are in harmony. Also, when Ozone is attacked by CFC, the warming of the atmosphere due to $\mathrm{CO}_{2}$, Ozone, Methane, etc, rejection, or by diverse other chemicals, which can lead to other consequences. It seems to me that the following disasters can be dangerous: global warming, impoverishment of the layer of the Ozone, degradation of the soil due to deforestation, erosions, climate change, pollution of waters, atmosphere and of soil. All of these are more or less the results of human industrial works in the pursuit of economic interests without caring for environment. God is interested in the welfare and survival of humankind as a whole and does not need to know what particular cultures or races think about. This means that we can either survive together or disappear together. The only spiritual blindness can lead some of us to believe that we can survive at the peril of others. Ecology generally insists on the relationship between nature and humankind as 
religions also do to some extent. For this reason, I think that, Africa can continuously fight for the protection of her environment in accordance with the regulations of God.

\section{Ecology and theology}

Being a Christian or not, the understanding of the world and relationship with nature have a religious foundation and a theological base. As for Monotheist religions, humankind is the centre of the world. After creating human beings according to his own likeness, God placed them outside the common nature and gave them the power to dominate it as a whole. But Polytheist religions consider humankind as a product of nature; while, religions called "primitive" and oriental religions consider humankind as a form of life among many others. Therefore, different theological world views emerge. Theologically, the arrangements of the world and the relationship with nature have a theological base because it is God who is the creator of anything and humanity is in the centre of all. Theologically, after creating human beings after his own similarity, God placed them above the common nature and gave them the capacity and the authority to dominate the whole of his creation. The dominion and protection of the creation of God, holistically, imply all the sectors of the human life including environment. The interdependence of all the creatures under the sun is a crucial personal discipline. Accordingly, Kyomo (2001) affirms "life is worthy of life when this discipline becomes the currency for each human being". And, this interdependence which exists between human being and nature has a great consideration in the African design because the African regards nature as part of his existence according to the will of God. Niwagile (1997) is of the view that "the African people should be completely comfortable with this crucial heritage". This causes a positive African answer to environmental protection, supportively; $\mathrm{Njah}$ (2001) explains the operation conditions saying "according to the attitudes and the values of the individuals and the communities towards their habitation". African intellectuals can hence "provide control and encourage associations in the care for the environment by inspiration, informing and allowing... to people to improve their quality of life without compromising that of the future generations"
(Njah 2001). Obviously, Africa needs the necessary information and knowledge to be able to solve ecological problems which disturb the life of the people, villages, provinces and various African countries. Affirm Fihavango (2001) "we have ambient need for healthy technologies adapted to prevent the ecological consequences which are dangerous for our health and safety, the health and the safety of the future generations". The African will thus easily live according to the vision of God, the creator of all good things for the blooming of the humanity. Each African will therefore understand the value of nature and the relationship, which exists between God, nature and human beings. Unfortunately, today, humanity is still dangerously able to destroy the good creation of God through various destructive means: massive weapon, pollution, and wars. Nuclear irresponsible engineering, industrialization and globalization also contribute to an unrestrained destruction of normal ecosystem. Consequently, Mwombeki (2001) advises "humans are obliged to take care of the environment as stewards because it, just as them, belongs to God". In the beginning was the word and the word were with God, and the word was God, it was in the beginning with God. Affirm John $(1: 1-3 ; 10: 10)$ "all the things were made by Him, and without Him nothing was done which was made". Christ is life, and the source of life for all the creation. Life is the quality needed for true existence in the kingdom of God; without Christ, there is no life. This life which is in Christ is expressed in his creation. Unfortunately, while Christ brings the abundant life to his creation, certain people and evil powers who direct the world try to work for the destruction and reduction of the value of the environment. All the life is sacred because it has its source in God by Christ, for that, African theologians should continuously re-examine theologically the behavior of the African people in relation to God as far as environmental protection is concerned in order to stimulate a responsible behavior in the life of the Africans with respect to God and his creation because God has never given the mandate to destroy Africa to anyone. On the contrary, he has entrusted the African the mission of protecting the environment. Acknowledging responsibility in this connection, Mugambi (2001) underlines: 
Of a theological point of view, we are all the culprits and victims at the same time. We are culprits with the eyes of our human beings and God when we take part in the destruction of the nature. After the fall of Adam and Eve, we are always guilty before God because of our basic disorientedness in life. Thus, in the ecological disaster we can see a collective call to the repentance. Moreover, the pains caused with us by environmental degradation could be seen like foreign work, thus God calls us to turn over in his grace. All the humanity is made in the image and the similarity of God and all the nature carries the marks of God.

This quotation is manifestly eloquent about God's will for his creation and it points straight to Africans responsibility. Accordingly, Psalm 104 underscores the fact that God created "all things". And in Mark (4:30-32) in the parable of the "mustard seed", Christ shows that God transmitted the protection of all the creatures to man however, the example of the young rich man written in Mark (10:17-22) seems to show that the "young rich man" was irresponsible in his daily behavior by refusing to make what was the thought of God. That is why I think that, African intellectuals should redynamise the God mission by showing that the total obedience to God in the protection of the environment is required if Africa wants to live the life in abundance according to the vision of God. Accordingly, Mugambi (2001) affirms that "clearly the guiding principle of equity is central to the Biblical tradition. God's inheritance is for the communal body, a concept that includes all of nature". The goal of the protection of environment is to support the health of the humankind and the rest of nature in their respective habitations. However, the threat of the climate change challenges all Africans to seek ways to live in order to stabilize the concentrations of $\mathrm{CO}_{2}$ in the atmosphere. A future of non-carbon energy is a necessity and realizable possibility. Add Mugambi (2001) "we can make changes in the ways that we live which will help to create the healthy and sustainable communities". Human societies change the chemical composition of the atmosphere by the excessive use of fossil fuels. Various gases with greenhouse effect, the carbon dioxide $\left(\mathrm{CO}^{2}\right)$ have the greatest impact. The $\mathrm{CO}^{2}$ is produced by the burning fossil fuels to produce the energy for electricity, industry and transport. Mugambi (2001) suggests further that to leave this environmental destruction, "the principalities and powers of this world will have to reconsider their exercise of clout and of influence, so that they may become leaders in the moral and theological sense, rather than masters and tyrants in the economic and political sense, respectively". Hence, ethical and moral norms can be applied to the macroeconomy and micro-economics, because the moral and spiritual values form the base no matter what people make in the economic and political sciences.

\section{Biblical views on environmental protection}

According to the word of God written in Gen $(1: 1,31)$ God is the "creator of all things" and all creations are in him. God saw that all his creation was good and before giving its responsibility to the humankind in order to keep it well and enjoy it. Unfortunately, the humankind chose to disobey him and to harm their environment. Along these lines Fihavango (2001) asserts "the fall caused an imbalance in the equilibrium of the creation. The problem was transferred from the broken relationship with God to the nature". Reason why, Psalm (23:12) shows how the good "behavior of God provides the good life in the nature". In the psalms (65:11-13; 148:7-10) the psalmist worships and praises God to have "created all good things However", the man/woman created in the image of God to enjoy all creatures, sinned and became malicious against God and against the nature. Consequently, they lost the privilege and the direct relationship with God and the humankind started thus to destroy the environment created by God. Also, Gen (3:14-24) affirm that the man and woman lost the blessing of being "co-governors" with God above the creation and the seeds of the rebellion damaged the relationship between humans and nature. The fact that humans sinned against God, destroyed the plan of God for the humanity. However, Bujo (1998) considers that "by Christ, the whole creation hopes for a new life in abundance and close relationship with God". But adversely Kyomo (2001) remarks, "it is the responsibility of 
every individual to preserve this life which is represented by the living and non-living". This safeguarding appears in environmental protection and climate change challenges. The reason why African intellectuals should show the African people the importance of protecting nature, is that the power and the glory of God are also indicated in the cosmos through trees, rivers, mountains, rocks, forests, animals, birds, etc.; all creation speaks a divine language claiming thus the fear and the veneration of God. The abundant life is enjoyed out only when the effective cure comprises the reconciliation of the whole cosmos. The community of the living and dead is also implied in this cure and reconciliation. Bujo (1998) underlines this fact stating "the human person and cosmos are supplemented at such point that they cannot exist without this interdependence".

Biblically, God penetrates all his creatures with his presence. This is why I estimate that, it is necessary to protect nature as God protects his people and works for the welfare of all. Later on Bujo (1998) advises "God penetrates all his creatures with his presence. Therefore we must not treat any of his creatures (any element, plant or animal) recklessly but deal with them in a sensitive manner, with empathy and reverence". The one who harms a creature harms God the creator himself and to enjoy abundant life human beings should respect the creation of God. The forest is human skin and if the skin of a human is removed the result is death. Death is to the door. Affirm Kyomo (2001) "we are authors of the shortage of rain because the climate is affected by the destruction of the environment". That is why Bujo (1998) reinforces this stating, "We cannot claim to be Christians (meaning the followers of Jesus the saved ones) if we engage in destruction of God's creation like deforestation". Theologically, this appeal concerns all the African intellectuals to popularize and work for environmental protection. According to Bookless (2008) "the creation is not our plaything or even our playground but has intrinsic value to God. Our use of natural resources in our lifestyles and our travel should be with restraint and respect". Such an attitude is reinforced by Christ teaching in Math (6:26-30) about God's providential "care for all creatures". Accordingly, Bujo (1998) affirms that "the onus is on all the Christians to link in order to save our environments of the destruction". I think that, the ecological therapy is only possible if the Africans completely examine their relationship with the nature concerning the essential force. African intellectuals should therefore conscientise the African people to protect Africa against all forms of the destruction of their nature and any form of ecological crisis because by protecting the environment, they protect themselves. Also, African theologians, through the Christian mission, can valuably accomplish this task because Christian mission has the power to attack all cause which destroys the environment and climate change challenges if it is well understood and contextualized according to the need of the moment, especially by putting Christ at the centre of all. Missiology also has mission to awaken Africans and to point out their responsibility towards God and the nature created by God. Theologically, it is necessary to understand the environmental crisis as a great "pastoral challenge in Africa" (Kyomo, 2001). As for Granberg (2007) the word of God furnishes four reasons why the environment should be cared for.

The first one is that it is the alliance of God with the earth and the living beings. The creation was chosen by God before he chooses and calls a people, he states. Secondly, the notion of nature as something apart, destined to be used, exploited and submitted that characterizes the industrial age results from the breakdown in the relationship between God, humanity and creation. Thirdly, Christ has come to reconcile and bring together all things, to restore a creation that groans and that waits for his redemption. And at last, the creation becomes a gift of grace, a gift that can be returned to God as an offering for the life of the world.

Obviously, a controversy seems to develop about this view. Zichichi (2007) think that "current information at our disposal does not allow us to affirm that human beings have something to do with global warming". And Idso (2007) states that "the release of $\mathrm{CO}^{2}$ is beneficial to the planet" and Grepaldi (2007) contends that the protection of the environment 
need not be a "pretext to reach two goals to prevent the economic development of the poorest countries, denying them a technological development that the North continues to improve; or else family planning policies aiming at restricting the growth of the population through birth control and abortion". Wenski (2008) observes that "the traditional virtue of caution suggests that we should not wait until we are absolutely sure of what will happen about the climate change in order to accept that something really harmful will take place". For me, it is more profitable to act now rather than wait until things worsen, and remedies become more expensive. Benoit XVI (2008) deems it useful to look for and "promote lifestyles and production and consumption models that have as aim the respect of the creation, and real demand for peoples' progress, and that take into account the universal destination of goods as that has often been repeated by the social doctrine of the church". And Tumi (2008) adds saying, "life comprises three dimensions: vegetal life, animal life and human life, therefore, protecting the environment amounts to protecting life". My views point is that, all creation, as the work of God, is sacred. Again, after the death and resurrection of Jesus Christ, there is no longer anything, profane, absolutely speaking. Every creation is saved in Christ, including nature. Hence, all the churches, not only the Catholic Church, because of their conviction that the whole creation is saved in Christ, and that God is the maker of everything that living creation, should be the vanguards for the protection of nature. Apparently, the church has always considered the proclamation of the gospel as its first mission. But, it should no longer preach the gospel to human beings as through they were angels, living in unnatural context. For that, the church should therefore consider the protection of the environment in which people live as an important part of their mission. The protection of the environment in which humans live should be taken seriously as part of the struggle for the restoration of the creation of God. So, the whole church has thus to speak of this matter with the same voice. In fact, Africa should continuously struggle to protect the environment because, theologically, protecting the nature may be understood as a priority for today's African intellectuals and theologians. Understanding our efficiency to change the world as something basically and firstly intrinsic to ourselves, Benoit XVI (2008) underlines "to change the world, let us change our own hearts". N'Kwim (1998:91) advises that "life is the most wonderful and immediate experience a human being can have in the world; that there is nothing which can ever replace it". The dream of everybody is to enjoy the longest living on the earth of the living. God also approves that not only for human beings but also for any other creature. Accordingly to religious, Islam/Koran considers water as a sign of God's mercy. Wherever brooks and dams are found in desert lands, this verse is put up, affirm Biber (2004) "We have made with water all the living things". As for Mohamed, even where water is abundant, no one is allowed to use more water than what is needed, because "God does not allow squandering". According to Animism, the Australian Timi aborigines live in symbiosis with the earth they use to paint their body. As for African animists, picking up an immature fruit or a flower is wrong for it prevents it from reaching maturity. But the Hinduism teaches that human life as well as animal and vegetal life is part of God's reincarnation and must be respected. And for the Shintoism in Japan, the nature is sacred. But this nature is supposed to be mastered, dressed by for millennia. I think that, the paragraphs above inform us that all these have religious knowledge and appreciation of nature though practical attitudes and reactions of some seem to be a terrible and dangerous syncretism. Alleges Douma (1991) "God's presence is also in any manifestation of life; that is also why they confer sacred character to trees and animals and declare them inviolable".

\section{Conclusion}

In the presence of such reckless and irresponsible actions against the creation of God, modality and solidarity can, theologically speaking, help to master the global environment in the spirit of responsibility and partnership with God in the management of the creation that God has put at the disposal of humankind. It is high time Africans in general and intellectuals in particular had stood up to protect the environment. Therefore, African theologians should continuously re-examine theologically the behavior of the African people in relation to God as far as environmental protection is concerned in order 
to stimulate a responsible behavior in the life of the Africans with respect to God and his creation because, God has never given the mandate to destroy Africa to anyone. On the contrary, he has entrusted the African the mission of protecting the environment, that is why African intellectuals should redynamise the God will by showing that the total obedience to God in the protection of the environment is required if Africa wants to live the life in abundance according to the vision of God. And, the goal of the protection of environment is to support the health of the humankind and the rest of nature in their respective habitations.

\section{References}

Benoit XVI, 2008. Journée mondiale de la paix. Bafoussam: Ecovox.

Biber, Privat 2004. Mission et environnement. Burundi: APM.

Bookless, D 2008. Christian Mission and Environmental Issues: An Evangelical

Reflection. Mission Studies 25 (2008): 37-52.

Bujo, B 1998. The ethical dimension of community: The African model and the dialogue

between north and south. Nairobi: Paulines.

Coste, R 2000. Les dimensions sociales de foi.

Paris: Cerf.

Douma, J 1991. Bible et écologie. Paris:

Kerygma.

Fihavango, G 2001. Quest for ecotheology in a situation of ecolological disaster, in

Christian Theology and Environmental Responsibility, edited by J.NK Mugambi

\& Mika Vähäkangas. Nairobi: Acton: 90-95.

Granberg, M 2007. Le monde doit prendre des

initiatives courageuses pour sauver la

planète. Bafoussam: Ecovox.
Grepaldi, G 2007. Poser la question, c'est déjà y répondre. Bafoussam: Ecovox.

Idso, C 2007. Le dégagement de CO2 est bénéfique pour la planète. Bafoussam: Ecovox.

Kyomo, A 2001. The environmental crisis as a pastoral challenge in Africa, in Christian

Theology and Environmental Responsibility, edited by J.NK Mugambi \& Mika

Vähäkangas. Nairobi: Acton: 57-63.

Mugambi, JNK \& Mika, V 2001. Christian

Theology and Environmental Responsibility.

Nairobi: Acton.

Mwombeki, F 2001. Ecology in the New

Testament, in Christian Theology and

Environmental Responsibility, edited by J.NK Mugambi \& Mika Vähäkangas.

Nairobi: Acton: 96-111.

Niwagile, W 1997. Our struggle for justice, peace and integrity of creation, in The

Church and Reconstruction of Africa, edited by Jess N.K Mugambi. Nairobi:

AACC.

Njah, PT 2001. Responding to global warming: An experience in Cameroon, in

Christian Theology and Environmental Responsibility, edited by J.NK Mugambi \& Mika Vähäkangas. Nairobi: Acton: 74-81.

N'Kwim, B 1998. Eglise et mission au seuil du $3^{\text {eme }}$ millénaire. Kinshasa: UPC.

Tron, F 1999. La nature a-t-elle une place auprès de l'homme. Yaounde: CIPCRE.

The Holy Bible 2001. English Standard Version. China: Bible Societies.

Tumi, C 2008. L'environnement, c'est la vie. Bafoussam: Ecovox.

Wenski, T 2008. La traditionnelle vertu de prudence. Bafoussam: Ecovox.

Zichichi, A 2007. Rapport avec le

réchauffement global. Bafoussam: Ecovox. 